\title{
Increase in the p21 expression independent of the 553 pathway in bleomycin-induced lung fibrosis
}

Article · January 2004

CITATIONS

0
READS

14

1 author:

\section{Renald Blundell}

University of Malta

107 PUBLICATIONS 84 CITATIONS

SEE PROFILE

Some of the authors of this publication are also working on these related projects:

Project regenerative medicine View project

Project Integrated Microalgae EXPlotaitation (I'mExp) from COST to EU call View project 


\title{
Increase in p21 expression independent of the p53 pathway in bleomycin-induced lung fibrosis
}

\author{
Renald Blundell ${ }^{\mathrm{a}, \mathrm{b}, *}$, Naftali Kaminski ${ }^{\mathrm{c}}$, David Harrison ${ }^{\mathrm{a}}$ \\ ${ }^{a}$ Department of Physiology and Biochemistry, University of Malta, Msida MSD06, Malta \\ ${ }^{\mathrm{b}}$ Pathology Department, Medical School, University of Edinburgh, Edinburgh Scotland, United Kingdom \\ ${ }^{\mathrm{c}}$ Lung Biology Center, University of California San Francisco, San Francisco, CA 94143, United States
}

Received 17 May 2004

Available online 8 September 2004

\begin{abstract}
Although a number of animal models have been used to study the pathogenesis of lung disease, to date few studies have looked at changed in the expression of cell cycle regulatory genes. We have studied the variation in the expression of p21, p53, p27 and PCNA in bleomycin-induced lung fibrosis using animal mouse models using immuno-histochemistry and gene-expression analysis. No difference in the p53, PCNA and p27 expressions were observed from the bleomycin-induced fibrosis when compared to saline-induced non-fibrotic lungs. Although no difference in nuclear p21 expression was observed, the level of cytoplasmic p21 expression was found to be higher in fibrotic lungs at day 14 after bleomycin injection. p21 expression was found to increase independent of p53 in fibrotic lungs at 14 days after bleomycin induction.
\end{abstract}

(C) 2004 Elsevier Inc. All rights reserved.

Keywords: Pulmonary fibrosis; Bleomycin; Lungs

\section{Introduction}

About $20 \%$ of the population worldwide die of lungrelated diseases, $17 \%$ of which are due to infections. Pulmonary fibrosis affects about 100,000 people in the United States.

Pulmonary interstitial fibrosis is defined as thickening and stiffening of the lining of the air sacs (alveoli) of the lungs causing progressive breathlessness (Cantin et al., 1987; Crouch, 1990; Crystal et al., 1976, 1978). The pathology of idiopathic pulmonary fibrosis (IPF) also known as cryptogenic fibrosing alveolitis (CFA) shows an initial alveolitis with persistent accumulation of inflammatory cells including neutrophils, alveolar macrophages, and lymphocytes in the lower respiratory tract. This is followed

\footnotetext{
* Corresponding author. Department of Physiology and Biochemistry, University of Malta, Biomedical Science Building, Msida MSD06, Malta.

E-mail address: renald.blundell@um.edu.mt (R. Blundell).
}

by parenchymal cell injury including extensive destruction of type I alveolar epithelial cells and repopulation of the epithelial cell surface by proliferating type II alveolar epithelial cells, resulting in alterations in lung extracellular matrix, fibroblast proliferation, and enhanced collagen synthesis with the accumulation of excess connective tissue in the lung (Cantin et al., 1987; Christensen et al., 1999; Crouch, 1990; Crystal et al., 1976, 1978).

Various animal models have been used to study the pathogenesis of lung disease, but to date few studies have looked at changes in expression of cell cycle control genes in these conditions. The p53 pathway was found to be involved upon exposure of lung epithelial cells to either hyperoxia (Barazzone et al., 1998; McGrath, 1998; O’Reilly et al., 1998) or to a number of DNA-damaging agents and carcinogens (Corroyer et al., 1996; Fujishita et al., 1995; Gadbois and Lehnert, 1997; Guinee et al., 1996). The expression of p16 (Sabourin et al., 1998), p21 (Guinee et al., 1996; McGrath, 1998), Rb (Fujishita et al., 1995; Sabourin et al., 1998), c-jun (Dolan et al., 1994; Haase et al., 1997), c-Fos (Haase et al., 
1997), TNF- $\alpha$ (Lee and Rannels, 1998; Yao et al., 1998), TGF$\beta$ (Lee and Rannels, 1998), BAX (Guinee et al., 1997), and Bcl-2 (Guinee et al., 1997) was reported to be influenced by a number of DNA-damaging agents and pollutants but the exact mechanism is still unclear.

In this current paper, we would like to describe the cellular pathology in these mouse lung models of the diseases and try to understand the molecular mechanisms.

The aim of this paper is to study the variation in the expression of p21, p53, p27, and PCNA and to describe the cellular pathology in bleomycin-induced lung fibrosis using animal mouse models. Understanding the cellular and molecular pathology of the diseases hopefully would lead to better and more effective diagnosis and treatment.

\section{Methods}

\section{Tissue sections}

Mouse tissue sections of bleomycin-induced fibrosis and saline treated (negative controls) were a kind gift of Prof. Thomas Strandjord, Department of Pediatrics, Seattle, USA. The method for bleomycin induction is described in Hormuzudi et al. (1999). A total of six mice were used, two bleomycin treated, two saline treated, and two untreated. In brief, specific pathogen-free homozygous C57BL/6 mice, 8-10 weeks old (18-25 g in weight) were treated with 3.5 $\mathrm{mU} / \mathrm{g}$ bleomycin sulfate in $2.33 \mu \mathrm{l} / \mathrm{g}$ sterile saline given via transtracheal puncture under intraperitoneal Avertin anesthesia. Lungs were harvested at 14 days after instillation overdose of intraperitoneal Avertin anesthesia and pulmonary arteries perfused with PBS. The left lung was fixed by intratracheal instillation of 4\% paraformaldehyde in PBS at $30 \mathrm{~cm} \mathrm{H}_{2} \mathrm{O}$ pressure for $2 \mathrm{~h}$, then fixed overnight in $4 \%$ paraformaldehyde in PBS at $4{ }^{\circ} \mathrm{C}$ and embedded in paraffin. For the bleomycin-negative control, the mice were treated with transtracheal sterile saline alone, $2.33 \mu \mathrm{l} / \mathrm{g}$.

\section{Antigen retrieval}

Paraffin tissue sections were placed in xylene for $15 \mathrm{~min}$. The sections were then transferred in a series of alcohol gradients from $100 \%$ to $74 \%$ to $64 \%$, and then tap water for $10 \mathrm{~min}$ each.

Table 1

Details of the primary antibodies used for immunohistochemistry and their relative concentrations

\begin{tabular}{|c|c|c|c|}
\hline $\begin{array}{l}\text { Antibody } \\
\text { against }\end{array}$ & Concentration & Supplier & $\begin{array}{l}\text { Catalogue } \\
\text { number }\end{array}$ \\
\hline $\mathrm{p} 21$ & $1 / 10$ & $\begin{array}{l}\text { DAKO, Bucke, } \\
\text { UK }\end{array}$ & M7207 \\
\hline p53 & $1 / 100$ & $\begin{array}{l}\text { Vector Lab, } \\
\text { Petersborough, UK }\end{array}$ & NCL-p53-CM5p \\
\hline p27 & $1 / 200$ & Sigma, Dorset, UK & P2092 \\
\hline PCNA & $1 / 5000$ & Sigma, Dorset UK & P8825 \\
\hline
\end{tabular}

DAKO antigen retrieval solution was prepared by diluting 1:100 with distilled water. A microwave dish was filled up with antigen retrieval solution and preheated in a microwave to boiling point. Slides that were dewaxed and rehydrated (as described above) were placed in a plastic slide rack and placed in a microwave dish containing the preheated antigen retrieval solution and were microwaved three times for $5 \mathrm{~min}$ each. The slides were allowed to cool for $30 \mathrm{~min}$ and then were rinsed with $\mathrm{H}_{2} \mathrm{O}$ and equilibrated in TBS.

\section{Immunohistochemistry}

Slides were equilibrated in TBS for $5 \mathrm{~min}$. The slides were blocked with an adequate serum in which the secondary antibody was raised. Primary antibody at a concentration specified in Table 1 was applied for $2 \mathrm{~h}$, followed by three 5-min washes with TBST. Secondary antibody was put on for $30 \mathrm{~min}$ then washed three times for 5 min each with TBST. An Alexa ${ }^{\mathrm{TM}}$-conjugated secondary antibody (diluted 1:200 in serum) was put on the slide and incubated for $3 \mathrm{~min}$. The slides were then washed three times for 5 min each and mounted using DAKO fluorescent mounting medium. The slides were then visualized under confocal microscope (Leica DM IRBE, Leica Micosystem, Cambridge, UK).

Three sections from each mouse were used for each gene studied. Immunohistochemistry scoring was performed by counting at least 100 cells at both the alveolar and bronchiolar regions. The degree, intensity, and localization of staining (i.e., either nuclear or cytoplasmic) were noted in each cell. Cell counting was repeated at least three times on each slide from both bleomycin- and saline-treated (control) mice. Confocal microscopy and histopathology analyses were carried out by both RB and DH independently.

\section{Gene expression studies}

The preparation of labeled cRNA, hybridization to microarrays, and analysis of Genechip data were carried out as previously described (Kaminski et al., 2000). Briefly, total RNA was isolated from pooled lungs of six mice from bleomycin-treated mice 7 or 14 days after treatment and from mice 7 days after saline injection. A separate group of control animals was sacrificed without any injection, and at least three animals were included in each experimental group. cRNA was prepared and hybridized to Genechip array. The Genechip array was then analyzed using Genechip 3.1 software (Affymetrix).

\section{Results \\ Histopathology}

The injury following intratracheal bleomycin tends to be patchy, which probably reflects where bleomycin droplets go, 

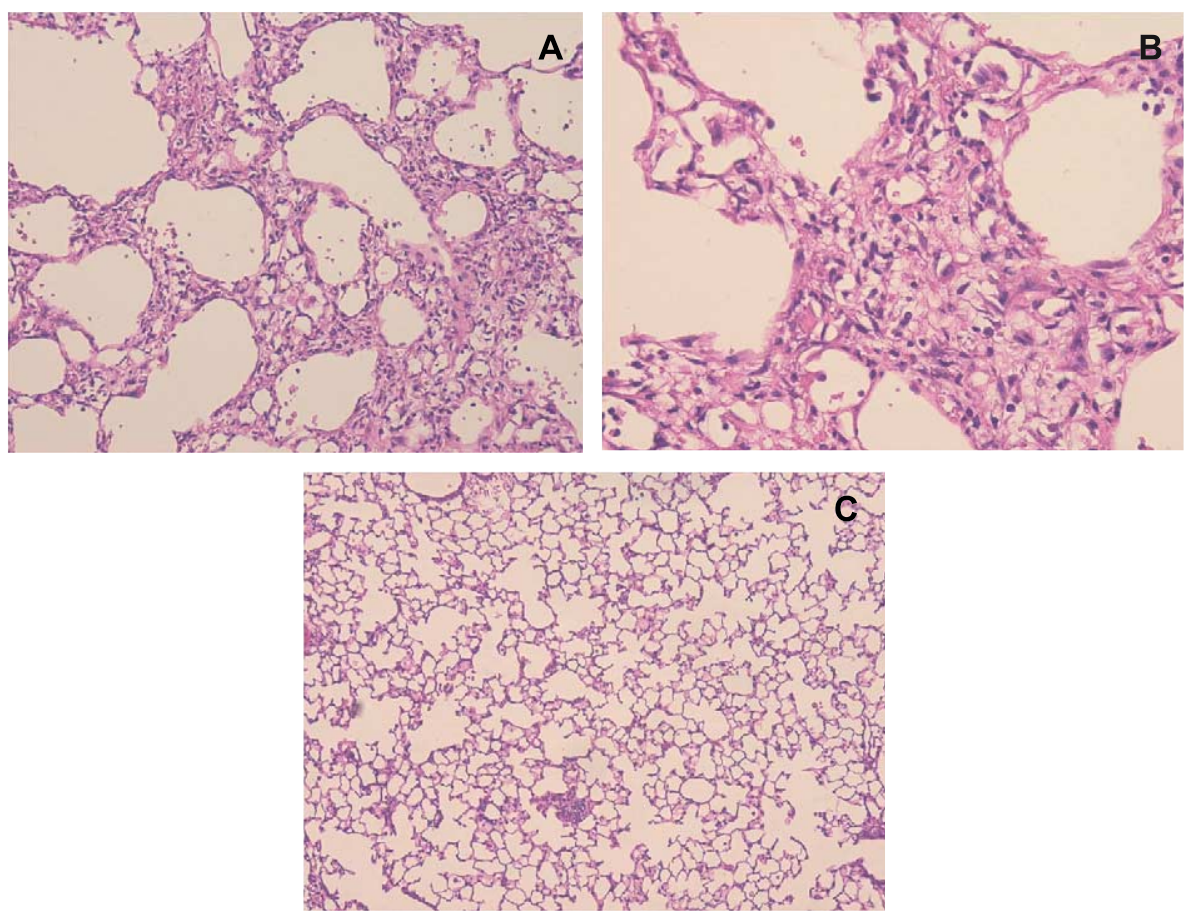

Fig. 1. Hematoxylin and eosin staining of bleomycin- and saline-treated mouse lung tissue sections. (A and B) Bleomycin-induced fibrosis at day 14, formalinfixed sections. Normal focal area of alveolar wall. Thickening with an increase in cells in the interstitium, most of which have spindle morphology typical of fibroblasts. Admixed within this are inflammatory cells including macrophages. (A) Magnification $\times 100$; (B) magnification $\times 400$. (C) Negative control (saline induced) at day 14, formalin-fixed sections. No significant abnormalities in the lung architecture. Magnification $\times 100$.

and variable in intensity. Later, the inflammatory response was fairly intense and widespread (Figs. 1A and B). The saline-treated lung appears completely normal (Fig. 1C).

\section{Immunohistochemistry}

There was no difference in the degree and intensity of staining of p53 and PCNA from the bleomycin-induced fibrosis lung sections compared to the saline-induced nonfibrotic lung tissue section (Figs. 2C-F). The degree of staining of p27 is the same in fibrotic tissue compared to the nonfibrotic but the intensity is higher (Figs. $2 \mathrm{G}$ and H). It is quite difficult to explain why since this could be an experimental artifact or that actually more cells are expressing or stabilizing more $\mathrm{p} 27$ following the bleomycin injury or disease. Although no difference in nuclear p21 expression was found, the level of cytoplasmic p21 expression (both degree and intensity of staining) is higher in the bronchiolar and alveolar regions in the fibrotic lung compared to the nonfibrotic lung tissue sections (Figs. 2A and B).

\section{Gene expression analysis}

The gene expression data for $\mathrm{p} 21, \mathrm{p} 53$, PCNA, and CC10 are shown in Table 2. From the data, it can be seen that $\mathrm{p} 53$ and PCNA did not change significantly from the fibrotic lungs generated by bleomycin-treated lungs at days 7 and 14 compared to the negative control, saline-treated lung. Two CC10 markers have been used, only one of which gave a significant result in the fibrotic lung at day 7. Thus, no significant conclusion can be obtained from the $\mathrm{CC} 10$ results.

An interesting result was obtained regarding $\mathrm{p} 21$ expression. The levels of $\mathrm{p} 21$ expression in fibrotic lung at 14 days were significantly higher $(P=0.05)$ when compared to the negative fibrotic lung. These data fit quite well with the results obtained by immunohistochemistry (Fig. 2), whereby p21 expression was found to be higher in the bleomycininjured lungs at day 14 compared to the negative fibrotic lung. From the immunohistochemistry studies, there was no variation in the levels of p53 and PCNA.

\section{Discussion}

Bleomycin, a potent cancer chemotherapeutic agent, causes fibrogenic lung disease in rats and mice similar to that seen in human subjects. Bleomycin affects many cellular pathways, but it is believed that the cytotoxic effect is due to its ability to bind and cleave DNA (Mori et al., 1989). A number of reports indicate that bleomycin generates reactive oxygen species in vitro (Daly et al., 1997, 1998; Mori et al., 1989; Wu et al., 1998b; Yi et al., 1998).

The p53 tumor suppressor protein is a DNA damageinducible protein (Albrechtsen et al., 1999; Ashcroft and Vousden, 1999; Brambilla and Brambilla, 1997; Kaelin, 1999a,b; Lane, 1992; Lakin and Jackson, 1999; Matlashewshi, 1999; May and May, 1999; Sheikh et al., 1997; Sigal and Rotter, 2000; Vogelstein et al., 2000; Wu et al., 1998a; 

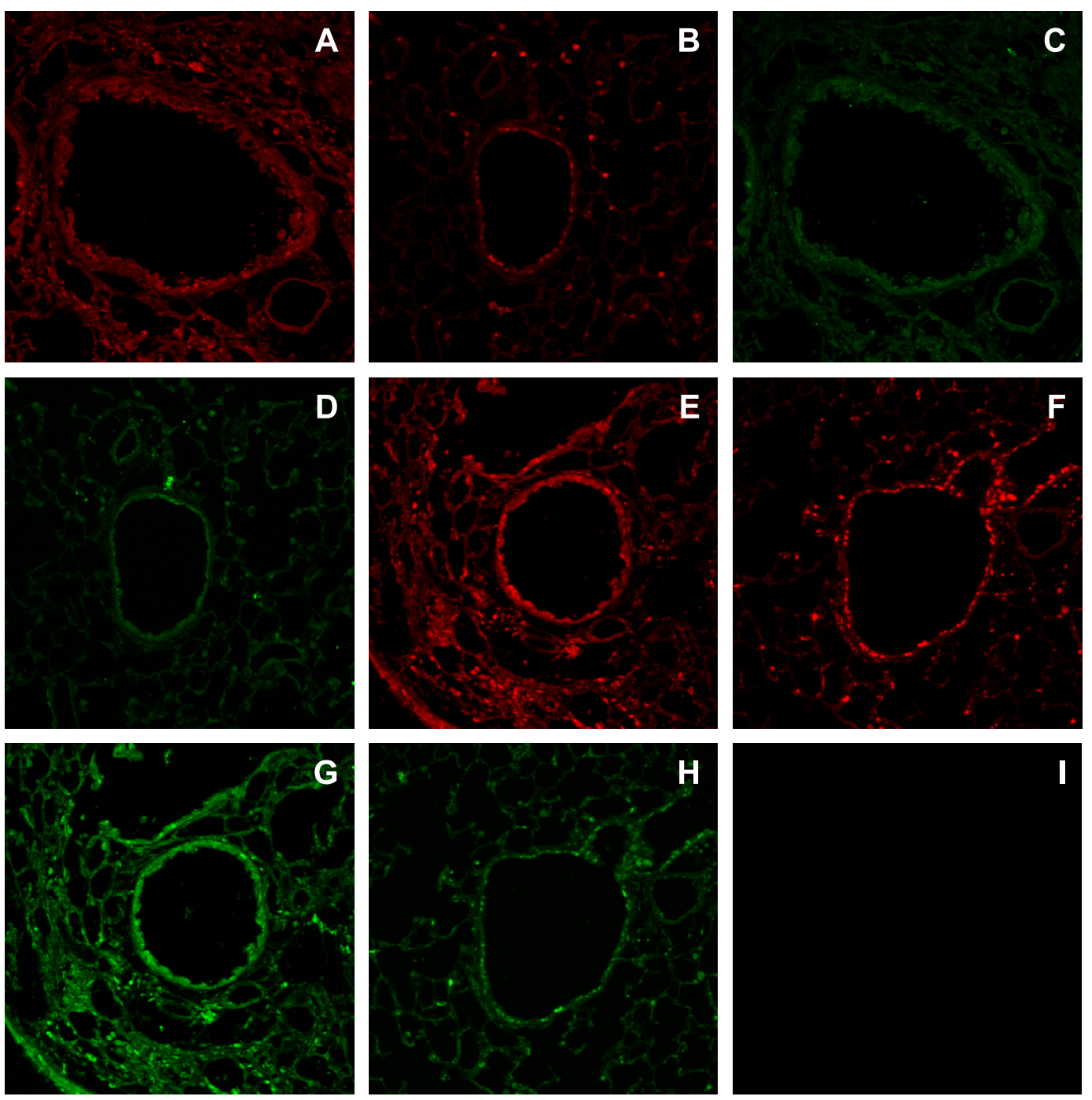

Fig. 2. Immunohistochemistry of bleomycin- and saline-treated mouse tissue sections. (A and B) p21 immunohistochemistry using Alexa ${ }^{\mathrm{TM}}$ 546-conjugated secondary antibody. Nuclear and cytoplasmic staining present in both alveolar and bronchiolar epithelial regions. p21 expression is greater in the fibrotic lung (A) and nonfibrotic lung (B). (C and D) p53 immunohistochemistry using Alexa ${ }^{\mathrm{TM}}$ 488-conjugated secondary antibody. Cytoplasmic staining present in both alveolar and bronchiolar epithelial regions in both fibrotic (C) and nonfibrotic lungs (D). (E and F) PCNA immunohistochemistry using Alexa ${ }^{\mathrm{TM}}$ 546conjugated secondary antibody. Nuclear and cytoplasmic staining present in both alveolar and bronchiolar epithelial regions. No difference between fibrotic (E) and nonfibrotic (F) lungs. ( $\mathrm{G}$ and $\mathrm{H}$ ) p27 immunohistochemistry using Alexa ${ }^{\mathrm{TM}} 488$-conjugated secondary antibody. Nuclear and cytoplasmic staining present in both alveolar and epithelial regions. An increase p27 expression in fibrotic (G) compared to nonfibrotic lungs (H). (I) Typical negative control whereby the primary antibody was omitted. Original magnification $\times 100$.

Wyllie et al., 1994; Zaika et al., 1999). Thus, one would expect to find an increase in p53 expression in bleomycininduced fibrosis model. In the bleomycin-induced fibrosis mouse model, there was no difference in the degree and intensity of staining of p53 in the fibrosis (at day 14) and nonfibrotic tissue sections. In the gene expression analysis, no statistically significant changes in the p53 expression were found in fibrotic lungs generated by bleomycin-treated lung at days 7 and 14 compared to the nonfibrotic lungs. Mishra et al. (2000) found that there was an increase p53 immunostaining in the lung cells of bleomycin-induced fibrosis tissue at days 3 and 7 but a decrease in day 9 and no evidence of p53 expression at day 14 .
In this study, no differences were found in the immunostaining of PCNA from the fibrotic (day 14) to nonfibrotic tissue. Also the degree of PCNA expression as determined by gene expression analysis was the same in fibrotic lungs (at days 7 and 14) and nonfibrotic lungs. These data were similar to the data by Mishra et al. (2000).

From immunostaining of $\mathrm{p} 21$, the level of $\mathrm{p} 21$ staining was found to be higher in fibrotic (day 14) tissue compared to nonfibrotic tissue. The level of p21 expression in fibrotic lungs at day 7 was not statistically higher when compared to the nonfibrotic lungs. At day 14, the expression of 21 was statistically higher $(P=0.05)$ when compared to nonfibrotic lungs. Mishra et al. (2000) found 
Table 2

Gene expression analysis on saline-treated lung (normal), bleomycin-treated (fibrosis day 7) and bleomycin-treated (fibrosis day 14) mouse lung

\begin{tabular}{|c|c|c|c|c|c|c|}
\hline Gene & $\begin{array}{l}\text { GenBank } \\
\text { Accession No. }\end{array}$ & $\begin{array}{l}\text { RNA levels } \\
\text { of normal lungs }\end{array}$ & $\begin{array}{l}\text { RNA levels } \\
\text { of fibrotic lungs at day } 7\end{array}$ & $\begin{array}{l}P \text { value } \\
\text { (fibrosis at day } \\
7 \text { vs. normal lungs) }\end{array}$ & $\begin{array}{l}\text { RNA levels } \\
\text { in fibrotic } \\
\text { lungs at day } 14\end{array}$ & $\begin{array}{l}P \text { value } \\
\text { (fibrosis at day } \\
14 \text { vs. normal lungs) }\end{array}$ \\
\hline p21 & U09507 & 231 & 392.7 & 0.12 & 435.3 & 0.05 \\
\hline $\mathrm{p} 53$ & U59758 & 30.8 & 25.0 & 0.77 & 66.7 & 0.31 \\
\hline p53 & X01237 & 187.2 & 146.7 & 0.57 & 162.3 & 0.74 \\
\hline PCNA & AA146128 & 20.0 & 13.3 & 0.42 & 20.0 & 1 \\
\hline PCNA & X57800 & 342.4 & 409.7 & 0.57 & 392.7 & 0.68 \\
\hline $\mathrm{CC} 10$ & AA028748 & 3119.2 & 3042.7 & 0.95 & 3138.0 & 0.98 \\
\hline $\mathrm{CC} 10$ & L24372 & 2282.8 & 1292.7 & 0.01 & 1789.3 & 0.21 \\
\hline
\end{tabular}

out that p21 overexpression at days 5 and 7 after exposure but the most intense p21 nuclear staining in epithelial cells was at day 9 .

The mRNA levels of p53 and p21 have been studied in bleomycin-induced fibrosis lungs at $1 \mathrm{~h}, 6 \mathrm{~h}, 1,3,5,7$, and 14 days by Kuwano et al. (1996, 2000). Kuwano et al. (2000) found out that lung mRNA levels of p53 and p21 were up-regulated at $1 \mathrm{~h}$ to day 7 after bleomycin instillation, while only p21 mRNA but not p53 mRNA was detectable at 14 days.

From the above data, it appears that following bleomycin induction, an increase in $\mathrm{p} 21$ induction via p53-dependent pathways may be involved. Since p53 was mainly induced in the early phase, it is likely that p53 may have an important role in the initial phase that is when DNA were mainly damaged by bleomycin itself but not at a later stage when DNA are damaged mainly by infiltrating inflammatory cells.p21 is most probably playing an important role in the p53-induced G1 arrest because it is a potential inhibitor of cyclin-dependent kinase activity (Cheng et al., 1999; Haapajärvi et al., 1999; Rousseau et al., 1999; Sheikh et al., 1997; Tomoda et al., 1999; Wu et al., 1998a). It has been shown previously that serum or individual growth factors such as platelet-derived growth factor, fibroblast growth factor, and epidermal growth factor but not insulin are able to induce p21 in quiescent p53-deficient cells as well as normal cells (Michieli et al., 1994). Thus, the induction of p21 without up-regulation of p53 mRNA at 14 days after bleomycin-induction may be dependent on growth factors, such as platelet-derived growth factor and fibroblast growth factor.

Apart from direct DNA damage from bleomycin and subsequent cell death, fibrosis could have resulted from inflammatory cell recruitment, fibroblast proliferation, or collagen synthesis. Inflammatory cells, including neutrophils and monocytes, can release toxic oxygen reactive species that can damage the DNA (Sato and Muramatsu, 1985; Sato et al., 1999).

Recent evidence suggests that cell-ECM interaction may be more important in modulating fibrosis than simple the degree of inflammation (Sheppard, 2001b). Although many of the normal lung development is still unknown, it is clear an important part of the network of reciprocal inductive and inhibitory signals involves the mesenchymal cells, pulmo- nary epithelial cells, and components of the ECM (Ebihara et al., 2000).

Several lines of evidence suggest that TGF- $\beta$ is involved in the regulation of pulmonary fibrosis (Coker et al., 1996; Gauldie et al., 2002). TGF- $\beta 1$ has been shown to be activated via integrins mainly $\alpha \mathrm{v} \beta 6$ (Sheppard, 2001a). The binding and activation of latent or inactive TGF- $\beta 1$ could be a mechanism whereby pulmonary fibrosis and inflammation could be regulation (Munger et al., 1999). It has also been shown that $\beta 6$ integrin expression is associated with sites of neutrophil influx in lung epithelium (Miller et al., 2001).

Mice that are homozygous for a null mutation of the $\beta 6$ subunit gene phenotypically exhibit pronounced lymphocyte accumulation in conducting airways, suggesting that the $\alpha \mathrm{v} \beta 6$ integrin complex may play a role in downregulating inflammation in the lung (Huang et al., 1996). $\beta 6$ knockout mice are protected from development of TGF- $\beta 1$ dependent bleomycin-induced pulmonary fibrosis, yet leukocyte recruitment into the lung after treatment with bleomycin was not inhibited (Munger et al., 1999). This further suggests the important role of $\alpha v \beta 6$ during inflammatory events in the airways.

From immunostaining, the degree of p27 staining was found to be the same but the intensity seems to be higher in fibrotic (day 14) tissue compared to nonfibrotic tissue. The increase in the degree of p27 staining could be either due to probable increase in TGF- $\beta$ or due to changes in cell-cell interactions (Llyod et al., 1999; Slingerland and Pagano, 2000). It is quite difficult to make any conclusions about p27 since the effects of TGF- $\beta$, rapamycin, and contact inhibition on cell proliferation remained unchanged in p27 null mice (Nakayama et al., 1996).

From the gene expression analysis studies, only one CC10 marker gave a significant result in fibrotic lung at day 7, but no significant conclusion can be made since only one of the $\mathrm{CC} 10$ was statistically significant. A decrease in the number of Clara cells evaluated by CC10 mRNA expression in the airway epithelial lining was described at 28 days following bleomycin induction (Daly et al., 1997). Daly et al. (1998) suggested that where CC10 mRNA expression was lost and SPB mRNA remained the same, the cells could be an intermediate cell type that is a precursor to either mature Clara cells or ciliated cells. 


\section{Conclusions}

p21 expression was found to increase independent of p53 at 14 days after bleomycin induction; thus, other factors such as cell-cell interactions, cell-integrin interactions, changes in ECM composition, and time scale could determine the expression of $\mathrm{p} 21$.

Since p21 is known to be involved in cell proliferation, death, and differentiation, it is important to study p21 expression in a progenitor cell type such as Clara cells. p21 was found to be expressed both in the cytoplasm and in the nucleus. From the literature, little is know about the functional role of cytoplasmic p21; thus, further studies need to be carried out to determine its role in lung injury and diseases.

\section{References}

Albrechtsen, N., Dornreiter, I., Grosse, F., Kim, E., Wiesmüller, L., Deppert, W., 1999. Maintenance of genomic integrity by p53: complementary roles for activated and nonactivated $\mathrm{p} 53$. Oncogene 18, 7717-7760.

Ashcroft, M., Vousden, K.H., 1999. Regulation of p53 stability. Oncogene $18,7637-7643$.

Barazzone, C., Horowitz, S., Donati, Y.R., Rodriguez, I., Piguet, P.-F., 1998. Oxygen toxicity in mouse lung: pathways to cell death. Am. J. Cell Mol. Biol. 19, 573-581.

Brambilla, E., Brambilla, C., 1997. p53 and lung cancer. Pathol. Biol. 45, $852-863$.

Cantin, A.M., North, S.L., Hubbard, R.C., Crystal, R.G., 1987. Oxidant mediated epithelial cell injury in idiopathic pulmonary fibrosis. J. Clin. Invest. 79, 1665-1673

Cheng, M., Olivier, P., Diehl, J.A., Fero, M., Roussel, M.F., Roberts, J.M., Sherr, C.J., 1999. The $\mathrm{p} 21^{\text {Cipl }}$ and $27^{\text {Kipl }}$ CDK 'inhibitors' are essential activators of cyclin D-dependent kinases in murine fibroblasts. EMBO J. 18, 1571-1583.

Christensen, P.J., Goodman, R.E., Pastoriza, L., Moore, B., Toews, G.B., 1999. Induction of lung fibrosis in the mouse by intratracheal instillation of fluorescein isothiocyanate is not T-cell dependent. Am. J. Pathol. 155, 1773-1779.

Coker, R.K., Laurent, G.J., Shahzeidi, S., Hernandez-Rodriguez, N.A., Pantelidis, P., du, B.R., Jeffery, P.K., McAnulty, R.J., 1996. Diverse cellular TGF-beta 1 and TGF-beta 3 gene expression in normal human and murine lung. Eur. Respir. J. 9, 2501-2507.

Corroyer, S., Maitre, B., Cazals, V., Clement, A., 1996. Altered regulation of G1 cyclins in oxidant-induced growth arrest of lung alveolar epithelial cells. J. Biol. Chem. 271, 25117-25125.

Crouch, E., 1990. Pathobiology of pulmonary fibrosis. Am. J. Physiol. 259, L159-L184.

Crystal, R.G., Fulmer, J.D., Roberts, W.C., Moss, M.L., Line, B.R., Reynolds, H.Y., 1976. Idiopathic pulmonary fibrosis: clinical, histologic, radiographic, physiologic, scintigraphic, cytologic and biochemical aspects. Annu. Intern. Med. 85, 769-788.

Crystal, R.G., Fulmer, J.D., Baum, B.J., 1978. Cells, collagen and idiopathic pulmonary fibrosis. Lung 155, 199-224.

Daly, H.E., Baecher-Allan, C.M., Barth, R.K., D’Angio, C.T., Finkelstein, J.N., 1997. Bleomycin induces strain-dependent alterations in the pattern of epithelial cell-specific marker expression in mouse lung. Toxicol. Appl. Pharmacol. 142, 303-310.

Daly, H.E., Baecher-Allan, C.M., Paxhia, A.T., Ryan, R.M., Barth, R.K., Finkelstein, J.N., 1998. Cell-specific gene expression reveals changes in epithelial cell populations after bleomycin treatment. Lab. Invest. 78, $393-400$.
Dolan, L.R., Rutberg, S.E., Amin, S., Emura, M., Mohr, U., Kraft, A., Yokoyama, K., Ronai, Z., 1994. Regulation of c-jun by lung carcinogens in Clara cells of hamsters. Carcinogenesis 12, 2785-2793.

Ebihara, T., Venkatesan, N., Tanaka, R., Ludwin, M.S., 2000. Changes in extracellular matrix and tissue viscoelasticity in bleomycin-induced lung fibrosis. Am. J. Respir. Crit. Care Med. 162, 1569-1576.

Fujishita, T., Mizushima, Y., Kashii, T., Kawasaki, A., Kobayashi, M., 1995. No occurence of DNA polymerase B gene mutation in human lung carcinoma cell lines with K-ras, $\mathrm{p} 53$, or $\mathrm{Rb}$ gene alterations. Oncology Reports 2, 755-757.

Gadbois, D.M., Lehnert, B.E., 1997. Cell cycle response to DNA damage differ in bronchial epithelial cells and lung fibroblasts. Cancer Res. 57, 3174-3179.

Gauldie, J., Kolb, M., Sime, P.J., 2002. A new direction in the pathogenesis of idiopathic pulmonary fibrosis? Respir. Res. 3, 1-3.

Guinee, D., Brambilla, E., Fleming, M., Hayashi, T., Rahn, M., Koss, M., Ferrans, V., Travis, W., 1997. The potential role of Bax and BCL-2 expression in diffuse alveolar damage. Am. J. Pathol. 151, 999-1007.

Guinee, D., Fleming, M., Hayashi, T., Woodward, M., Zhang, J., Walls, J., Koss, M., Ferrans, V., Travis, W., 1996. Association of p53 and WAF1 expression with apoptosis in diffuse alveolar damage. Am. J. Pathol. $149,531-538$.

Haapajärvi, T., Kivinen, L., Heiskanen, A., des Bordes, C., Datto, M.B., Wang, X.-F., Laiho, M., 1999. UV radiation is a transcriptional inducer of $\mathrm{p} 21^{\mathrm{Cip} 1 / \text { Wafl }}$ Cyclin-Kinase inhibitor in a p-53-independent manner. Exp. Cell Res. 248, 272-279.

Haase, M., Koslowski, R., Lengnick, A., Hahn, R., Wenzel, K.W., Schuh, D., Kasper, M., Muller, M., 1997. Cellular distribution of c-Jun and cFos in rat lung before and after bleomycin induced injury. Virchows Archiv 431, 441-448.

Hormuzudi, S.G., Strandjord, T.P., Madtes, D.K., Bornstein, P., 1999. Mice with a targeted intronic deletion in the Collal gene respond to bleomycin-induced pulmonary fibrosis with increased expression of the mutant allele. Matrix Biol. 18, 287-294.

Huang, X.Z., Wu, J.F., Cass, D., Erle, D.J., Corry, D., Young, S.G., Farese, R.V., Sheppard, D., 1996. Inactivation of the integrin beta 6 subunit gene reveals a role of epithelial integrins in regulating inflammation in the lung and skin. J. Cell Biol. 133, 921-928.

Kaelin, W.G., 1999a. The emerging p53 gene family. J. Natl. Cancer Inst. 91, 594-598.

Kaelin, W.G., 1999b. The p53 gene family. Oncogene 18, 7701-7705.

Kaminski, N., Allard, J.D., Pittet, J.F., Zuo, F., Griffiths, M.J.D., Morris, D., Huang, X., Sheppard, D., Heller, R.A., 2000. Global analysis of gene expression in pulmonary fibrosis reveals distinct programs regulating lung inflammation and fibrosis. Proc. Natl. Acad. Sci. U. S. A. 97, $1778-1783$.

Kuwano, K., Kunitake, R., Kawasaki, M., Nomoto, Y., Hagimoto, N., Nakanishi, Y., Hara, N., 1996. p21 Waf1/Cip1/Sdil and p53 expression in association with DNA strand breaks in idiopathic pulmonary fibrosis. Am. J. Respir. Crit. Care Med. 154, 477-483.

Kuwano, K., Hagimoto, N., Tanaka, T., Kawasaki, M., Kunitake, R., Miyazaki, H., Kaneko, Y., Matsuba, T., Maeyama, T., Hara, N., 2000. Expression of apoptosis-regulatory genes in epithelial cells in pulmonary fibrosis mice. J. Pathol. 190, 221-229.

Lakin, N.D., Jackson, S.P., 1999. Regulation of p53 in response to DNA damage. Oncogene 18, 7644-7655.

Lane, D.P., 1992. P53, guardian of the genome. Nature 358, 15-17.

Lee, Y.-C., Rannels, D.E., 1998. Regulation of extracellular matrix synthesis by TNF $\alpha$ and TGF $\beta 1$ in type II cells exposed to coal dust. Am. J. Physiol. 275, L637-L644.

Llyod, R.V., Erickson, L.A., Jin, L., Kulig, E., Qian, X., Cheville, J.C., Scheithauer, B.W., 1999. p2 $7^{\text {kip1 }}$ : a multifunctional cyclin-dependent kinase inhibitor with prognostic significance in human cancers. Am. J. Pathol. 154, 313-323.

Matlashewshi, G., 1999. p53: twenty years on meeting review. Oncogene $18,7618-7620$. 
May, P., May, E., 1999. Twenty years of p53 research: structural and function aspects of the p53 protein. Oncogene 18, 7621-7636.

McGrath, S.A., 1998. Induction of $\mathrm{p} 21^{\mathrm{WAF} 1 / \mathrm{CIP} 1}$ during hyperoxia. Am. J. Cell Mol. Biol. 18, 179-187.

Michieli, P.M., Chedid, M., Lin, D., Pierce, J.H., Mercer, W.E., Givol, D., 1994. Induction of WAF1/CIP1 by a p53-independent pathways. Cancer Res. 54, 3391-3395.

Miller, L.A., Barnett, N.L., Sheppard, D., Hyde, D.M., 2001. Expression of the $\beta 6$ integrin subunit is associated with sites of neutrophil influx in lung epithelium. J. Histochem. Cytochem. 49, 41-47.

Mishra, A., Doyle, N.A., Martin, W.J., 2000. Bleomycin-mediated pulmonary toxicity. Am. J. Resir. Cell Mol. Biol. 22, 543-549.

Mori, S., Seki, S., Oda, T., 1989. Studies on bleomycin-induced repair DNA synthesis in permeable mouse ascites sarcoma cells. Acta Med. Okayama 43, 81-88.

Munger, J.S., Huang, X., Kawakatsu, H., Griffiths, M.J.D., Dalton, S.L., Wu, J., Pittet, J.F., Kaminshi, N., Garat, C., Matthay, M.A., Rifkin, D.B., Sheppard, D., 1999. The integrin $\alpha \mathrm{v} \beta 6$ binds and activated TGF $\beta 1$ : a mechanism for regulating pulmonary inflammation and fibrosis. Cell 96, 319-328.

Nakayama, K., Ishida, N., Shirane, H., Inomata, A., Inoue, T., Shishido, N., Horii, I., Loh, D.Y., Nakayama, K.I., 1996. Mice lacking p2 $27^{\text {Kip1 }}$ display increase body size, multiple organ hyperplasia, retinal dysplasia and pituitary tumors. Cell 85, 707-720.

O’Reilly, M.A., Staversky, R.J., Stripp, B.R., Finkelstein, J.B., 1998. Exposure to hyperoxia induced p53 expression in mouse lung epithelium. Am. J. Resp. Cell Mol. Biol. 18, 43-50.

Rousseau, D., Cannella, D., Boulairs, J., Fitzgerald, P., Fotedar, A., Fotedar, R., 1999. Growth inhibition of CDK-cyclin and PCNA binding domains by 21 occurs by distinct mechanisms and is regulated by ubiquitinproteasome pathways. Oncogene 18, 4313-4325.

Sabourin, C.L.K., Wang, Q.-S., Ralston, S.L., Evans, J., Coate, J., Herzog, C.R., Jones, S.L., Weghorst, C.M., Kellof, G.J., Lubet, R.A., You, M., Stoner, G.D., 1998. Expression of cell cycle proteins in 4-(methylnitrosamino)-1-(3-pyridyl)-1-butanone-induced mouse lung tumours. Exp. Lung Res. 24, 499-521.

Sato, M., Muramatsu, T., 1985. Reactivity of five $N$-acetylgalactosaminerecognizing lectins with preimplantation embryos, early postimplantation embryos, and teratocarcinoma cells of the mouse. Differentiation $29,29-38$.

Sato, E., Koyama, S., Masubuchi, T., Takamizawa, A., Kubo, K., Nagal, S., Izumi, T., 1999. Bleomycin stimulates lung epithelial cells to release neutrophil and monocyte chemotactic activities. Am. J. Physiol. 276, L941-L950.

Sheikh, M.S., Chen, Y.Q., Smith, M.L., Fornace, A.J., 1997. Role of

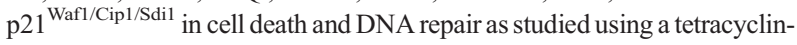
inducible system in p53-deficient cells. Oncogene 14, 1875-1882.

Sheppard, D., 2001a. Integrin-mediated activation of transforming growth factor-beta(1) in pulmonary fibrosis. Chest $121,49 \mathrm{~S}-53 \mathrm{~S}$.

Sheppard, D., 2001b. Pulmonary fibrosis: a cellular overreaction or a failure of communication. J. Clin. Invest. 107, 1501-1502.

Sigal, A., Rotter, V., 2000. Oncogenic mutations of the p53 tumor suppressor: the demons of the guardian of the genome. Cancer Res. 60, 6793.

Slingerland, J., Pagano, M., 2000. Regulation of the cdk inhibitor p27 and its deregulation in cancer. J. Cell Physiol. 183, 10-17.

Tomoda, K., Kubota, Y., Kato, J., 1999. Degradation of the cyclin-dependentkinase inhibitor p27Kip1 is instigated by Jab1. Nature 398, 160-165.

Vogelstein, B., Lane, D., Levine, A.J., 2000. Surfing the p53 network. Nature 408, 307-310.

Wu, M., Bellas, R.E., Shen, J., Sonenshein, G.E., 1998. Roles of the tumor suppressor $\mathrm{p} 53$ and the cyclin-dependent kinase inhibitor $\mathrm{p} 21^{\mathrm{WAF} 1 / \mathrm{CIP} 1}$ in receptor-mediated apoptosis of WEH1 231 B lymphoma cells. J. Exp. Med. 187, 1671-1679.

Wu, X., Gu, J., Amos, C.I., Jiang, H., Hong, W.K., Spitz, M.R., 1998. A parallel study of in vitro sensitivity to Benzo(a)pyrene diol expoxide and bleomycin in lung carcinoma cases and controls. Cancer 83, $1118-1127$.

Wyllie, A.H., Carder, P.J., Clarke, A.R., Cripps, K.J., Gledhill, S., Greaves, M.F., Griffiths, S., Harrison, D.J., Hooper, M.L., Morris, R.G., Purdie, C.A., Bird, C.C., 1994. Apoptosis in carcinogesis: the role of p53. Cold Spring Harbor Symp. Quant. Biol. 16, 403-409.

Yao, X.L., Levine, S.J., Cowan, M.J., Logun, C., Shelhamer, J.H., 1998. Tumor necrosis factor- $\alpha$ stimulates human Clara cell secretory protein production by human airway epithelial cells. Am. J. Cell Mol. Biol. 19, 629-635.

Yi, E.S., Salgado, M., Williams, S., Kim, S.J., Masliah, E., Yin, S., Ulich, T.R., 1998. Keratinocyte growth factor decreases pulmonary edema, transforming growth factor-beta and platelet-derived growth factor-BB expression, and alveolar type II cell loss in bleomycin-induced lung injury. Inflammation 22, 315-325.

Zaika, A., Marchenko, N., Moll, U.M., 1999. Cytoplasmically "sequestered" wild type p53 protein is resistant to Mdm2-mediated degradation. J. Biol. Chem. 274, 27474-27480. 